\title{
Efforts To Improve Student Learning Activities Using The Students Activity Sheet In Class IX-2 SMPN 32 Padang
}

\section{Upaya Meningkatkan Aktifitas Belajar Siswa Menggunakan Lembaran Kegiatan Siswa Pada Mapel IPA Kelas IX-2 SMPN 32 Padang}

\author{
Doris Yelniwetis ${ }^{1}$, Qadriati ${ }^{1}, \operatorname{Ramli}^{1}$, Mitra Miswarni ${ }^{1}$, dan Yurnita ${ }^{1}$ \\ ${ }^{1)}$ KKG IPA SMPN 32 Padang \\ Jl. Sei. Lareh Lubuk Minturun Kota Padang \\ Email:dorisyelniwetis@gmail.com
}

\begin{abstract}
Science is an important field of study to support science and technology. Many efforts have been made to improve the quality of education such as curriculum change, teacher competency improvement to stimulate student activities and the provision of learning resources. One that can be implemented to improve the quality of education through increased student activity is to multiply the source of learning such as LKS. This study aims to determine the increase in student learning activities using student activity sheets on IX-2 class IX-2 SMPN 32 Padang. Research includes classroom action research. From the data analysis, it can be concluded that there is an increase of student activity on the subject of Science class VII SMPN 32 Padang using Student Activity Sheet.
\end{abstract}

Keywords: science, activities and student activity sheets

\section{PENDAHULUAN}

Paradigma pendidikan telah mengalami perubahan konsep pandang tentang hubungan antara pendidik dengan peserta didik yang bergeser dari pendidikan yang berpusat pada guru ke pendidikan yang berpusat pada peserta didik. Peserta didik merupakan objek sekaligus subjek pendidikan. Siswa sebagai objek peserta didik mendapat perlakuan-perlakuan dalam pembelajaran. Siswa sebagai subjek peserta didik merupakan salah satu komponen untuk terlaksananya proses pendidikan (Wicaksono, Minarti, \& Roshayanti, 2018).

Pada kurikulum 2013 peserta didik merupakan subjek pendidikan, kurikulum ini lebih menekankan pada pengembangan kompetensi setiap individual peserta didik. Peserta didik dituntut untuk lebih aktif belajar, mencari informasi dan melakukan eksplorasi sendiri atau berkelompok. Guru lebih banyak berperan sebagai komunikator, fasilitator dan motifator untuk memudahkan peserta didik mendapatkan sumber belajar sehingga mereka dapat melakukan kegiatan belajar secara optimal (Friatma, Helendra, \& Syamsurizal, 2017).

Salah satu karakteristik mata pelajaran IPA adalah adanya praktikum dan laboratorium sarana utama proses pembelajaran IPA, dimana salah satu tujuan 
kegiatan laboratorium menghendaki keterlibatan dan peran aktif peserta didik secara utuh. Karakteristik mata pelajaran IPA tersebut akan tercermin dalam pelaksanaan kegiatan pembelajaran. Guru berusaha semaksimal mungkin untuk memilih metoda, strategi dan media pengajaran yang relevan agar peserta didik seluruhnya terlibat dan berperan aktif secara utuh sehingga pembelajaran bermakna bagi peserta didik. Aktifitas belajar peserta didik yang optimal akan menentukan tingkat pemahaman dan hasil belajarnya (Septiani, Darussyamsu, \& Syamsurizal, 2017).

Menurut pengamatan peneliti yang ditemui pada SMPN 32 Kota Padang sekarang ini motivasi yang dimiliki peserta didik sangat rendah sehingga aktifitas belajar belum maksimal. Pembelajaran IPA selama ini penetili lakukan dengan menggunakan metode ceramah dan diskusi dengan diselingi gambar sketsa di papan tulis. Refleksi awal aktifitas peserta didik yang aktif bertanya pada teman dalam kelompok sebanyak 7,90\%, aktif menjawab pertanyaan guru 5,26\%, aktif bertanya pada guru 5, 26\%, aktif menjawab pertanyaan teman 7,90\% dan aktif menanggapi jawaban teman 10,53\%, aktif mencatat kesimpulan diskusi 92,11\% dari 38 orang peserta didik kelas IX - 2

Kondisi pembelajaran diatas jika tidak dicarikan solusinya, maka tujuan pembelajaran yang diharapkan tidak tercapai secara maksimal dan hasil belajar peserta didik akan motivasi peserta didik sehingga nantinya diharapkan hasil belajar dan kualitas pembelajaran IPA meningkat. Salah satu upaya yang perlu dilakukan dalam meningkatkan aktifitas belajar peserta didik adalah dengan menggunakan strategi pembelajaran dengan memakai Lembaran Kegiatan Siswa ( LKS ).

Lembaran Kegiatan Siswa (LKS) adalah lembaran kertas mengandung petunjuk kerja dimana peserta didik dapat memperoleh tuntutan urutan kerja dan mengisikan hasil kerja didalamnya, karena dengan adanya LKS tentu peserta didik akan belajar secara mandiri dan belajar memahami serta menyelesaikan tugas-tugas tertulis yang ada dalam LKS. Dengan harapan keterlibatan dan peran aktif peserta didik akan terlihat secara optimal, sehingga hasil belajar meningkat (Widoretno \& Frida, 2014).

LKS bagi guru dapat dijadikan acuan evaluasi dan masukan informasi dalam system pembelajaran secara keseluruhan, disamping itu manfaat LKS bagi guru menurut Darmojo (1992) adalah: Memudahkan guru mengarahkan PBM; Membantu guru mengarahkan peserta didik untuk dapat; Menemukan konsep-konsep ilmu pengetahuan; Memudahkan guru untuk memantau keberhasilan peserta didik untuk mencapai sasaran belajar.

Bagi peserta didik, LKS bermanfaat atau berperan sebagai: Membimbing dan memberi petunjuk dalam melaksanakan Kegiatan belajar mengajar; LKS merupakan tempat mencatat hasil pelajaran yang berguna untuk mendapatkan kesimpulan; LKS dapat mengarahkan peserta didik dalam mengambil Keputusan; Peserta didik terbiasa mengikuti petunjuk tertulis dalam Pembelajaran; LKS dapat membantu peserta didik menilai pekerjaan sendiri. 
Setiap peserta didik secara individual maupun kelompok aktif melaksanakan kegiatan mengisi lembaran-lembaran tugas yang harus dikerjakan oleh peserta didik, karena dengan adanya LKS tentu peserta didik akan belajar secara mandiri dan belajar memahami serta menyelesaikan tugas-tugas tertulis yang ada dalam LKS. Dengan demikian akan muncul rasa tanggung jawab pada masing-masing induvidu. Keterlibatan dan peran aktif peserta didik akan terlihat secara optimal . Berdasarkan hal di atas dilakukan penelitian tindakan kelas dengan judul “ Upaya Meningkatkan Aktifitas Belajar IPA Menggunakan Lembaran Kegiatan Siswa (LKS) Pada Kelas IX-2 SMPN 32 Padang “.

Berdasarkan latar belakang masalah di atas, masalah penelitian ini dapat dirumuskan sebagai berikut: "Apakah terdapat peningkatan aktifitas belajar IPA dengan menggunakan LKS pada peserta didik kelas IX-2 SMPN 32 Padang ?"

Penelitian ini bertujuan untuk mengetahui peningkatan aktifitas belajar siswa kelas IX-2 SMPN 32 Padang melalui strategi pembelajaran dengan menggunakan LKS.

\section{METODE PENELITIAN}

Penelitian ini berupa penelitian tindakan kelas (PTK). PTK ini terdiri dari dua siklus dan tiap siklus terdiri dari tiga kali pertemuan. Setiap siklus memiliki sintak: perencanaan (planning), tindakan (action), pengamatan (observation) dan refleksi. Sebelum masuk siklus I terlebih dahulu diadakan refleksi awal sebagai perenungan siklus I. Penelitian dilakukan di SMPN 32 Padang pada semester 2 pada materi pelajaran Genetika tahun pelajaran 2016/2017. Waktu penelitian bulan Januari-Juli 2017. Subjek penelitian peserta didik kelas IX-2 SMPN 32 Padang yang berjumlah 36 orang, terdiri dari 16 orang laki-laki dan 20 orang perempuan.

Variabel terikat penelitian adalah aktifitas belajar peserta didik, sedangkan variabel bebasnya adalah LKS. Jenis data yang diolah adalah data primer yang diperoleh secara langsung dari aktifitas belajar peserta didik.

Instrumen yang digunakan dalam penelitian ini adalah lembaran pengamatan aktifitas peserta didik yang diisi oleh pengamat. Aspek-aspek yang diamati sebagai kategori aktifitas peserta didik, sebagai berikut: Peserta didik yang bertanya pada teman sekelompok peserta didik yang menjawab pertanyaan guru; Peserta didik yang bertanya pada guru; Peserta didik yang menjawab pertanyaan teman sebaya; Peserta didik yang menanggapi jawaban teman; Peserta didik yang mencatat kesimpulan diskusi dan Peserta didik yang mengerjakan LKS 


\section{Refleksi Awal}

Berdasarkan pengamatan penulis di kelas IX-2 terlihat selama proses pembelajaran berlangsung kelas tampak pasif, peserta didik yang aktif rata-rata hanya $21,49 \%$, seperti yang terlihat pada Table 1 .

Table 1. Persentase aktifitas peserta didik pada refleksi awal.

\begin{tabular}{clcr}
\hline No & Aktifitas Peserta Didik & Jumlah & $\%$ \\
\hline 1 & Peserta didik yang bertanya pada teman sekelompok & 3 & 7,90 \\
2 & Menjawab pertanyaan guru & 2 & 5,26 \\
3 & Bertanya pada guru & 2 & 5,26 \\
4 & Menjawab pertanyaan teman & 2 & 7,90 \\
5 & Menanggapi jawaban teman & 2 & 10,53 \\
6 & Mencatat kesimpulan diskusi & 35 & 92,11 \\
7 & Mengerjakan LKS & 0 & 0,00 \\
\hline
\end{tabular}

Untuk meningkatkan aktifitas peserta didik seoptimal mungkin, maka perlu tindakan pada siklus I

\section{Siklus I}

a. Perencanaan (Planning)

Beberapa kegiatan yang dilakukan pada tahap perencanaan adalah sebagai berikut :

1. Menentukan standat kompetensi dan kompetensi dasar dalam pembelajaran

2. Menyiapkan perangkat pembelajaran melalui kajian kurikulum yang berlaku mulai dari materi pembelajaran, alokasi waktu, indikator pencapaian serta rencana pembelajaran

3. Merancang bentuk LKS yang akan di isi oleh peserta didik

4. Merancang bentuk media untuk mendukung kegiatan pembelajaran

5. Merancang instrument penelitian, instrument pada penelitian ini adalah lembar observasi dan tes hasil belajar

b. Tindakan (Action)

Adapun tindakan yang dilakukan adalah sebagai berikut:

1. Peserta didik dibagi menjadi 10 kelompok yang heterogen, masing-masing kelompok terdiri dari 3 dan 4 orang

2. Guru membagikan LKS kepada peserta didik

3. Guru menjelaskan mekanisme kerja kelompok dan cara kerja LKS

4. Setelah pembukaan pelajaran guru memberikan pertanyaan motivasi yang menyangkut dengan konsep yang dipelajari serta memberikan penjelasan jika ada pertanyaan dari peserta didik. Guru lebih banyak mengajukan pertanyaan untuk menggiring peserta didik berpikir sehingga terlibat secara aktif dalam pembelajaran dan mengemukakan jawabannya, sambil menulis judul pelajaran pada hari itu di papan tulis 
5. Peserta didik mengisi LKS dan menjawab pertanyaan dalam LKS bersama kelompoknya

6. Guru memberikan penjelasan menyangkut dengan pertanyaan yang ada pada LKS apabila peserta didik menemukan kesulitan dalam menyelesaikannya

7. Kelompok yang pertama selesai diberi aplus kemudian diberi kesempatan ketua kelompok untuk mempresentasikan hasil diskusinya di depan kelas.

8. Kelompok yang tidak tampil presentasi diberi kesempatan untuk bertanya dan memberikan saran terhadap kelompok yang presentasi

9. Pada saat diskusi kelompok dan diskusi kelas, guru mendampingi dan membimbing peserta didik untuk membantu menjelaskan tentang berbagai permasalahan yang ditemui peserta didik.

10. Peserta didik dibawah bimbingan guru membuat kesimpulan tentang kegiatan yang sudah dilaksanakan.

11. Guru mengumpulkan LKS

12. Guru memeriksa LKS dan memberikannya kembali pada pertemuan berikutnya.

c. Pengamatan (observation)

Pengamatan dilakukan oleh pengamat yang telah ditunjuk untuk mengamati aktifitas peserta didik yang meliputi:

1. Peserta didik yang bertanya pada teman sekelompok

2. Peserta didik yang menjawab pertanyaan guru

3. Peserta didik yang bertanya pada guru

4. Peserta didik yang menjawab pertanyaan teman

5. Peserta didik yang menanggapi jawaban teman

6. Peserta didik yang mencatat kesimpulan diskusi

7. Peserta didik yang mengerjakan LKS

Aktifitas tersebut dicatat oleh pengamat selama proses pembelajaran

d. Evaluasi dan refleksi

Hasil refleksi siklus I dijadikan perenungan refleksi awal untuk siklus II, sekiranya penulis belum merasa puas terhadap hasil siklus I, maka penulis akan melanjutkan dengan siklus II, dimana pelaksanaan siklus II ini sama dengan siklus I tetapi ditambah dengan beberapa action (tindakan), seperti:

1. Meminjamkan buku paket kepada peserta didik untuk dibawa pulang tiga hari sebelum penelitian dilakukan

2. Menyuruh peserta didik untuk mempelajari materi pelajaran di rumah terlebih dahulu

3. Memberitahukan sebelumnya kepada peserta didik, kalau kelompok yang paling aktif akan mendapat hadiah agar mereka termotivasi untuk belajar 
Untuk memperbaiki kekurangan tersebut perlu dilakukan perencanaan untuk siklus II

\section{Siklus II}

a. Refleksi awal

Refleksi awal pada siklus II adalah hasil refleksi pada siklus I

b. Perencanaan (planning)

1. Guru membuat perangkat pembelajaran dengan materi Ekosistem lengkap dengan perencanaan pembelajaran dan indikator, LKS, lembar pengamatan dan tes hasil belajar

2. Meminjankan buku paket pada peserta didik untuk dibawa pulang tiga hari sebelum penelitian dilakukan.

3. Menyuruh peserta didik untuk mempelajari materi pelajaran di rumah terlebih dahulu

4. Memberitahukan sebelumnya kepada peserta didik, kalau kelompok yang paling aktif akan mendapat hadiah agar mereka termotivasi untuk belajar

c. Tindakan (action)

Adapun tindakan yang dilakukan guru adalah sebagai berikut:

1. Peserta didik duduk dalam kelompoknya masing-masing.

2. Guru membagikan LKS

3. Guru menjelaskan mekanisme kerja kelompok dan adanya reward bagi kelompok yang aktif

4. Guru membuka pelajaran, mengajukan pertanyaan, memotivasi sambil menuliskan judul pelajaran hari itu di papan tulis.

5. Peserta didik mengisi LKS bersama kelompoknya secara berdiskusi

6. Sambil berkeliling guru memberikan penjelasan, bertanya dan menjawab pertanyaan bila ada peserta didik yang menemui kesulitan dalam mengisi LKS

7. Kelompok yang selesai diskusi pertama kali diberi aplus sebagai penghargaan diberi kesempatan untuk mempresentasikan hasil diskusi kelompoknya dan diberi hadiah berupa buku tulis sebanyak anggota kelompok dan disalami

8. Kelompok yang tidak tampil diberi kesempatan bertanya dan memberikan saran.

9. Guru mengumpulkan LKS

10. Guru memeriksa LKS dan memberikannya kembali di pertemuan berikutnya.

d. Pengamatan (observation)

Hal yang diamati pada siklus II sama dengan yang dilakukan pada siklus I

e. Evaluasi dan Refleksi

Hasil refleksi pada siklus II diharapkan meningkat dari siklus I dari segala aspek 
aktifitas yang diteliti.

Pada penelitian ini, data yang terkumpul diolah dengan tehnik presentil yang dipresentasekan dengan menggunakan rumus:

$$
\mathrm{P}=\mathrm{F} / \mathrm{N} \times 100 \%
$$

Dimana : $\quad \mathrm{P}=$ persentase peserta didik yang aktif

$\mathrm{F}=$ jumlah peserta didik yang aktif

$\mathrm{N}=$ jumlah peserta didik yang hadir saat pengamatan

Menurut Arikunto (1996) interpretasi adalah sebagai berikut :
a. $81 \%-100 \%=$ tinggi sekali
b. $61 \%-80 \%=$ tinggi
c. $41 \%-60 \%=$ sedang
d. $21 \%-40 \%=$ rendah
e. $0 \%-20 \%=$ rendah sekali

\section{HASIL PENELITIAN DAN PEMBAHASAN}

Hasil refleksi yang telah dilaksanakan pada kedua siklus, diperoleh data aktivitas siswa dan perhitungan jumlah dan persentase aktivitas tiap siklus. Untuk lebih jelasnya dapat dilihat pada Tabel 1 .

Table 1. Persentase aktifitas peserta didik pada refleksi awal, siklus II dan siklus II pada 36 siswa

\begin{tabular}{|c|c|c|c|c|c|c|}
\hline \multirow{2}{*}{ Parameter Pengamatan } & \multicolumn{2}{|c|}{ Refleksi awal } & \multicolumn{2}{|l|}{ Siklus I } & \multicolumn{2}{|c|}{ Siklus II } \\
\hline & Jumlah & $\%$ & Jumlah & $\%$ & Jumlah & $\%$ \\
\hline Bertanya pada teman & 6 & 16.7 & 10 & 27.8 & 12 & 33.3 \\
\hline Menjawab pertanyaan guru & 4 & 11.1 & 9 & 25.0 & 10 & 27.8 \\
\hline Bertanya pada guru & 5 & 13.9 & 10 & 27.8 & 12 & 33.3 \\
\hline Menjawab pertanyaan teman & 4 & 11.1 & 8 & 22.2 & 10 & 27.8 \\
\hline Menanggapi jawaban teman & 6 & 16.7 & 8 & 22.2 & 11 & 30.6 \\
\hline Mencatat kesimpulan diskusi & 35 & 97.2 & 36 & 100.0 & 36 & 100.0 \\
\hline Mengerjakan LKS & 24 & 66.7 & 36 & 100.0 & 36 & 100.0 \\
\hline
\end{tabular}




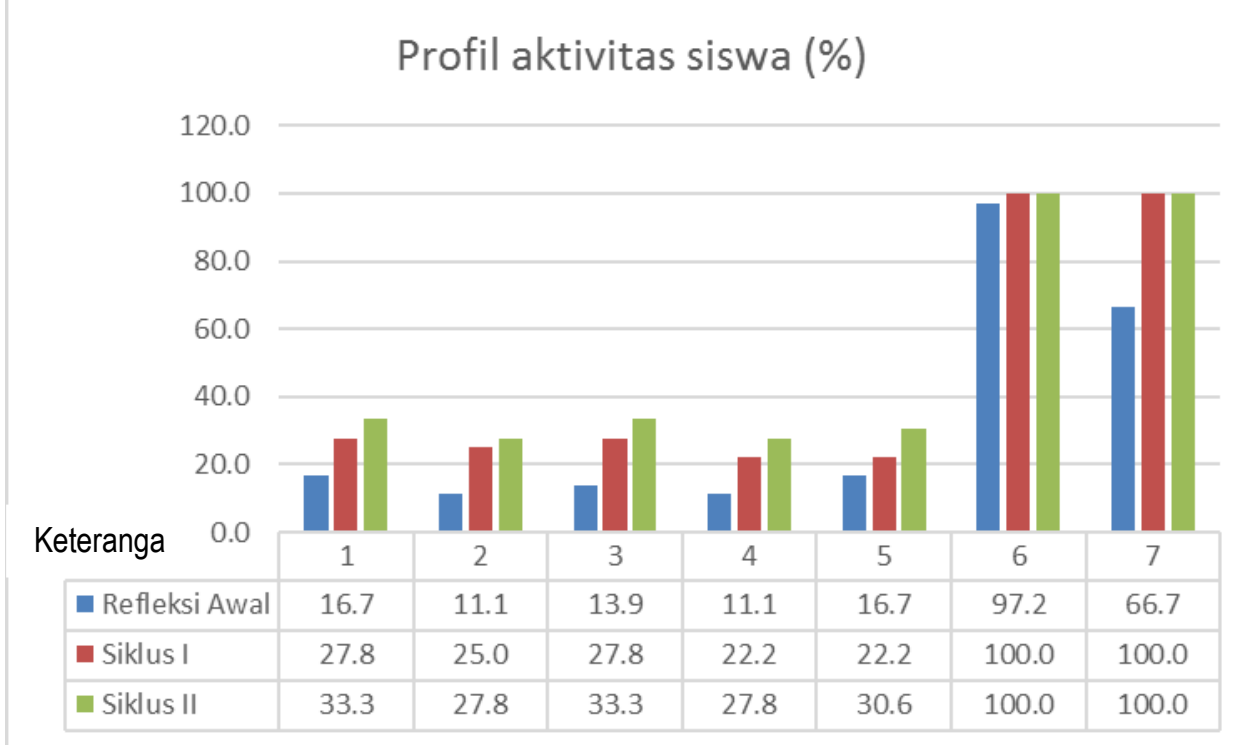

1. Bertanya pada teman

5. Menanggapi jawaban teman

2. Menjawab pertanyaan guru

6. Mencatat kesimpulan diskusi

3. Bertanya pada guru

7. Mengerjakan LKS

4. Menjawab pertanyaan teman

Berdasarkan hasil analisis data didapatkan aktifitas siswa yang dalam pembelajarannya menggunakan LKS lebih aktif dari biasanya. Peningkatan aktifitas siswa dengan LKS diduga karena beberapa hal, diantaranya:

Pemakaian LKS merupakan cara belajar kelompok yang menekankan siswa untuk saling bekerja sama dengan sesama siswa. Setiap siswa harus bertanggung jawab terhadap tugas yang didapatkan karena setiap kelompok akan mempresentasikan hasil diskusinya di depan kelas. Dalam diskusi kelompok setiap siswa akan merasa bertanggung jawab sehingga pola berfikir kritis siswa berkembang (Amin \& Adiansyah, 2018).

Pemakaian LKS memberikan kesempatan kepada kelompok untuk mempresentasikan hasil diskusi kelompoknya. Presentasi mendidik siswa saling menghargai perbedaan, memanfaatkan kelebihan tiap kelompok dan mengisi kekurangan masing-masing kelompok (Lie, 2002).

Pemakaian LKS memberikan keuntungan pada pelaksanaan dan efektivitas program pengajaran. Siswa tidak perlu banyak bertanya kepada kawannya karena sudah dipandu dalam LKS sehingga siswa lebih aktif dalam pembelajaran (Mashudi \& Kholis, 2015). 
Pemakaian LKS dapat meningkatkan kepercayaan diri siswa dalam proses belajar mengajar, antara lain: Memperbaiki hubungan sosial; Meningkatkan kemahiran kepemimpinan; Meningkatkan rasa percaya diri.

Penggunaan LKS sangat membantu siswa meningkatkan pemahaman dalam menangkap materi pelajaran. Jika siswa ditugaskan untuk membuat LKS maka siswa akan lebih aktif untuk belajar. Keaktifan siswa yang dalam pembelajaran menggunakan LKS terlihat pada waktu diskusi. Siswa lebih berani mengemukakan pendapat (Baharun, 2015).

Untuk topik yang terpilih, ketika guru menerangkan siswa lebih banyak menunjukkan antusiasme seperti mengemukakan pendapat, bertanya dan memberikan tanggapan. Partisipasi siswa yang lebih aktif dengan penggunaan LKS disebabkan siswa telah membaca dan memahami konsep-konsep materi yang akan dipelajari di sekolah (tindakan siklus II). Hal ini juga menyebabkan siswa dapat belajar secara bermakna. Pemahaman yang baik dari materi pelajaran yang telah dipelajari dan materi pelajaran yang akan dipelajari dalam proses pembelajaran di sekolah membangkitkan minat dan motivasi siswa untuk mengikuti pelajaran yang berlangsung, dan hal itu akan memberikan dampak yang baik terhadap aktifitas (Ivo, Darussyamsu, \& Syamsurizal, 2017).

Pembuatan LKS dapat memaksa siswa untuk berfikir tentang isi materi supaya mengenal dan menguji konsep-konsep penting, mengelompokkan konsepkonsep tersebut, menggambarkan hubungan antara konsep-konsep dan menilai maknanya, serta membuat kaitan atau hubungan yang menggunakan banyak berfikir kritis. LKS juga dapat membantu mengetahui adanya miskonsepsi (kesalahan konsep) dari siswa dan membantu untuk memperbaiki kesalahan konsep yang diterima siswa sebagai dasar untuk pelajaran selanjutnya sehingga akhirnya efektif untuk merubah kesalahan konsep yang diterima siswa.

\section{PENUTUP}

Aktifitas belajar siswa meningkatkan menggunakan lembaran kegiatan siswa pada mapel IPA kelas IX-2 SMPN 32 Padang. 


\section{UCAPAN TERIMA KASIH}

Pada kesempatan ini, Kami mengucapkan terima kasih kepada Rektor Universitas Negeri Padang, LP2M dan Tim Pengabdian Masyarakat FMIPA yang telah membantu kami dalam penyamaan persepsi tentang PTK dan memberikan insentif kepada KKG IPA SMPN 32 Padang untuk melaksanakan PTK.

\section{REFERENSI}

Amin, Astuti Muh., \& Adiansyah, Romi. (2018). Lecturers' Perception On Students' Critical Thinking Skills Development And Problems Faced By Students In Developing Their Critical Thinking Skills. Jurnal Pendidikan Biologi Indonesia, 4(1), 1-10. doi: 10.22219/jpbi.v4i1.5181

Baharun, H. (2015). Penerapan Pembelajaran Active Learning untuk Meningkatkan Hasil Belajar Siswa di Madrasah. Jurnal Pendidikan Pedagogik, 1(1), 34-46.

Friatma, A., Helendra, \& Syamsurizal. (2017). Analisis Kualitas Soal Ujian Akhir Semester Genap Mata Pelajaran Biologi Kelas XI IPA SMA Negeri Wilayah Selatan Kabupaten Solok Tahun Pelajaran 2015/2016. Bioeducation Journal, 1(2), 50-67.

Novidsa, I., Darussyamsu, R. \& Syamsurizal. (2017). Peningkatan Kompetensi Sikap Peserta Didik Dengan Penerapan Strategi Learning Community Melalui Model Pembelajaran Inkuiri Pada Materi Struktur dan Fungsi Jaringan Tumbuhan Kelas VIII Di SMPN 12 Padang. Bioeducation Journal, 1(2), 8796.

Mashudi, M., \& Kholis, N. (2015). Pengaruh Model Pembelajaran Aktif Dengan Metode Active Debate Terhadap Hasil Belajar Pada Standar Kompetensi Memperbaiki CD Player Di Smkn 2 Surabaya. Jurnal Pendidikan Teknik Elektro, 4(3), 747-751.

Septiani, V., Darussyamsu, R., \& Syamsurizal. (2017). Peningkatan Kompetensi Keterampilan Peserta Didik dengan Penerapan Strategi Learning Community melalui Model Pembelajaran Jigsaw pada Materi Sistem Pencernaan Manusia Kelas VIII di SMPN 12 Padang. Bioeducation Journal, 1(2), 117-126.

Wicaksono, A. G. C., Minarti, I. B., \& Roshayanti, F. (2018). Analysis of Students' Science Motivation and Nature of Science Comprehension in Middle School. Jurnal Pendidikan Biologi Indonesia, 4(1), 35-42.

Widoretno, P, \& Frida, N. (2014). Pengembangan LKS Dengan Pembelajaran Berbasis Masalah Pada Materi Diagram Gaya Normal, Gaya Lintang, Dan Momen Di Kelas X Tgb 1 SMK Negeri 1 Sidoarjo. Jurnal Kajian Pendidikan Teknik Bangunan, 3(1), 44-49.

Silberman, M. L. 2006. Active Learning: 101 Cara Belajar Siswa Aktif. Terjemahan Raisaul Muttaqien. Bandung: Nusamedia. 